\title{
Prevalence of Antibiotic Resistant Vibrio spp. in Finfish Sold in Tripoli Fish Markets, Libya
}

\author{
Emad Ramadan Abodaia ${ }^{1}$, Hanan Lotfi Eshamah ${ }^{2}{ }^{\circledR}$, Hesham Taher Naas ${ }^{2 *}$ \\ ${ }^{1}$ Department of Microbiology, Marine Biology Research Center (MBRC), Tajoura, Libya \\ ${ }^{2}$ Department of Food Hygiene and Safety, Faculty of Veterinary Medicine, Tripoli University, Libya
}

\begin{abstract}
Background: The occurrence of Vibrio spp. in raw fish is common, especially from temperate climates regions, in both natural and farm environments, and in all kind of fish. Whereas, limited data have been reported on antibiotic resistance strains of Vibrio spp. Aim: The main objectives of this study were to determine the prevalence of Vibrio spp. including antibiotic resistance strains in fresh finfish samples as well as evaluation of their antibiogram. Material and methods: Samples of 122 fresh finfish were purchased from two main fish markets in Tripoli, Libya. Samples were examined for the presence of Vibrio spp. and its antibiogram. Results: A total of 68 Vibrio's belonging to six different species were isolated, the most predominant species were V. fluvialis $45(66.2 \%)$, followed by V. alginolyticus $10(14.7 \%)$, V. cholera $9(13.2 \%)$, V. parahemolyticus $2(2.9 \%)$, V. vulnificus and V. hollisae $1(1.5 \%)$. All of the isolates showed different degree of resistance toward tested antibiotics. The isolates showed high resistance to cloxacillin, amoxicillin, vancomycin, amoxicillin/clavulanic acid, oxytetracylin, cephalothin, while for streptomycin the resistance rate was the lowest. Conclusion: The results demonstrated a high incidence of Vibrio spp. in raw finfish samples and this finding suggests that, fish sold in Tripoli fish markets could be a source of potential health hazard. This is because some of isolated strains were resistant to most popular antibiotics used in human and aquaculture treatments. Besides, study results indicated that, antibiotic resistance strains are common in raw finfish sold in both markets. Improvements in handling and processing are needed to minimize the prevalence of such pathogenic bacteria.
\end{abstract}

Keywords: Vibrio spp., Finfish, Mullet, Sardine, Antibiotic Resistance.

Received: August 30, 2020 / Accepted: November 13, 2020 / Published: December 04, 2020

\section{Introduction}

Vibrio spp. from the family Vibrionaceae, defined as Gramnegative, asporogenous rod or curved rod-shaped, motile, fermentative, oxidase-positive (except two species), catalase positive, it gives a positive indole reaction and facultative anaerobes. Vibrio spp. are ubiquitous organism of the saprophytic microbiota which are usually isolated in the spring and summer from marine sources i.e.: depend on water temperature greater than $10^{\circ} \mathrm{C}^{1}$. Vibrio spp. is widespread in the marine environment, particularly in tropical and temperate waters, and they represent the major bacterial pathogens affecting fish farming in the Mediterranean Sea ${ }^{2}$. Fish constitute an important food component for a large section of the world population; they come after meat and poultry meat as major animal protein foods, where fish is considered a cheap source of protein. In general, seafood comprises one of the fastest growing sources of food; billions of people throughout the world rely on fish as a primary source of protein ${ }^{3}$. Fish and their products are responsible for a substantial proportion of foodborne diseases worldwide, it has been found to be responsible for major foodborne outbreaks worldwide ${ }^{4}$. In contrast to most other foodborne pathogens, Vibrio spp. have the aquatic habitat as their natural niche. The majority of fish borne bacteria are natural inhabitant in aquatic environment and all can live independently from fish host ${ }^{5}$.

Food security is a complex issue, where various factors pose a condition of risk to fish food safety and they range from contamination from the environment where it is caught up to contamination by the consumer before eating ${ }^{6}$. One of the major risks involves the consumption of raw or undercooked seafood that may be naturally contaminated by foodborne pathogens present in the marine environment. Such risk is further increased if the food is mishandled during processing where pathogens could multiply exponentially under favorable conditions. The extensive use of antimicrobial drugs in human disease treatment and agriculture led to a significant increase in the spread and persistence of antibiotic resistance in the environment ${ }^{7}$. The public health hazards related to antimicrobial use in aquaculture include the development and spread of antimicrobial resistant bacteria and resistance genes, and the existence of antimicrobial residues in aquaculture products. As a consequence, antibiotic resistance phenomena, with the occurrence and spread of determinants of resistance to antibiotics, have become one of the most serious emerging threats in aquaculture ${ }^{8}$.

* Corresponding author: Hesham Taher Naas, Department of Food Hygiene and Safety, Faculty of Veterinary Medicine, Tripoli University. P.O. Box. 13662, Libya. E-mail: H.naas@uot.edu.ly 
Antimicrobial use in treatment of humans and food animal husbandry (terrestrial and aquatic) results in the release of wastes that carry both antibiotics and antibiotic resistant (ABR) bacteria into the terrestrial and coastal marine environment ${ }^{9}$. The development of antimicrobial resistance among pathogenic bacteria has emerged as a major public health concern, which has led to an intensification of discussion about the prudent use of antimicrobial agents, antimicrobial agents persist in sediment and aquatic environments, leading to deteriorated environmental conditions and conferring antimicrobial resistance to the sediment bacteria ${ }^{6}$. Antibiotic resistant bacteria may represent a potential threat to human health due to direct transmission through the food chain, or by transferring the acquired antimicrobial resistance to human pathogens by mobile genetic elements ${ }^{10}$.

In Libya, sea waters are the main receptacles for these pollutants, since they receive the sewage (un-treated) of urban effluents, this pollution may contribute to the maintenance and even the spread of antibiotic resistance bacteria ${ }^{11}$. Fish and shellfish farmers are recently facing risks related to the persistence of residues of antimicrobial drugs in seafood products as well as to the selection and spread of resistance to antibiotics both in animal and environmental bacterial population ${ }^{8}$. Fish could serve as delivery vehicles of antimicrobial resistance to pathogenic bacteria from aquatic environments to humans and from one country to another ${ }^{12}$. Nowadays, pollution of coastal areas represents one of the most important environmental problems because it causes economic and tourism damages as well as affects health quality. This emerging issue has gained great concern due to increased resistance of pathogenic Vibrios toward clinically used antimicrobials ${ }^{13}$. Extensive use of antimicrobial agents in fish farming and the consequent selective pressure lead to the acquisition of antibiotic resistance in aquaculture environment bacteria.

The development of antibiotic resistance by Vibrio represents a potential threat to human health by exchange of resistant genes to human pathogens through food chain ${ }^{14}$. Some studies suggest that multidrug resistant (MDR) Vibrio spp. are rampant in seafood, which obtain antibiotic resistance via plasmids or other mobile genetic elements ${ }^{15}$. The continuous monitoring and surveillance of MDR bacteria in fish and fish handlers will not only reduce the risk of disease to the fish but also public health hazards to fish handlers and consumers in general ${ }^{16}$. Therefore, the objectives of this study were to isolate Vibrio spp. from fresh finfish samples sold in Tripoli fish markets, and to determine its antibiotics susceptibility patterns of isolated and identified Vibrio spp. strains.

\section{Material and Methods}

\subsection{Fish Sampling}

A total of 122 fresh finfish samples were randomly collected from different sellers at two major household markets in Tripoli Libya (Souq Almadena and Souq Bab-albher).

Samples included Sardine $(\mathrm{n}=62)$ and Mullet $(\mathrm{n}=60)$ selection was according to fish living behavior, Mullet; pelagic fish are usually located from the surface down to $15 \mathrm{~m}$ depth, gregarious, while, Sardine; pelagic, neritic, are usually found in the surface down to $350 \mathrm{~m}$ depth, gregarious, oceanodromous ${ }^{17}$.

The aseptic procedure was strictly applied during the collection, transportation, and analysis of the samples according to FDA ${ }^{18}$. The finfish samples were collected and individually marked in sterile polyethylene bags, kept in the insulated icebox and transported directly to Quality Control, and Disease of Marine Living Organisms laboratory, Marine Biology Research Center (MBRC), Tajoura - Libya, for microbiological assay.

\subsection{Sample Preparation and Isolation of Vibrio spp.}

The microbiological analysis was performed as described by standard methods adopted from FDA ${ }^{18}$. Briefly, swabbing technique of skin surface and gills of each fish sample was performed according to Austin ${ }^{19}$. The swab sample was enriched in $10 \mathrm{ml}$ of Alkaline Peptone Water broth (Liofilchem, Italy) and incubated at $35 \pm 2^{\circ} \mathrm{C}$ for $18-24 \mathrm{~h}$. A loopful of each culture broth aseptically streaked onto dried surface of Thiosulphate Citrate Bile Salts Sucrose Agar (Liofilchem, Italy) plates, and then incubated at $35 \pm 2^{\circ} \mathrm{C}$ for $18-24 \mathrm{~h}$. Suspected colonies (yellow-greenish yellow) were picked up and streaked onto Nutrient Agar (Liofilchem, Italy) plates supplemented by $3 \% \mathrm{NaCl}$ (Riedel-DeHaen, Germany), and incubated at $35 \pm 2{ }^{\circ} \mathrm{C}$ for $18-24 \mathrm{~h}$ for purification.

\subsection{Identification of Vibrio spp.}

The isolates were identified at the species level by using biochemical tests. The purified isolates were tested for Gram stain and positive oxidase test. For the oxidase test, bacterial colonies were transferred with a sterile glass rod to filter paper moistened with oxidase reagent ${ }^{20}$.

Rapid appearance of a dark purple color within few seconds was considered a positive reaction, each primary identified colony was inoculated in to normal saline and mixed with vortex, then, inoculated into wells of API 20E kit (API, Biomerieux, France), and incubated at $35 \pm 2^{\circ} \mathrm{C}$ for $24 \mathrm{~h}$ as described by Kaysner et al. ${ }^{21}$, then identification of suspected Vibrio spp. was done according to company software (www.biomerieux.com).

\subsection{Antibiogram of Isolated Vibrio spp. Strains}

\subsubsection{Inoculum Preparation}

Upon confirmation of isolated strains by API software, confirmed isolates were kept at $4^{\circ} \mathrm{C}$ on Nutrient Agar plates which supplemented with $3 \% \mathrm{NaCl}$ (Liofilchem, Italy). To propagate the isolates, one colony was inoculated into $5 \mathrm{~mL}$ of Brain Heart Infusion broth (Liofilchem, Italy) supplemented with $3 \% \mathrm{NaCl}$ and incubated for $18 \mathrm{~h}$ at $35 \pm 2^{\circ} \mathrm{C}$.

\subsubsection{Selection of Antibiotics}

Antibiotics discs were selected among the most commonly use in aquaculture and human therapy that include; amoxicillin, cephalothin, oxytetracylin, streptomycin ${ }^{14}$. The tested antibiotics included amoxicillin $(10 \mu \mathrm{g})$, amoxicillin/clavulanic acid $(30 \mu \mathrm{g})$, cephalothin $(\mathrm{KF} 30 \mu \mathrm{g})$, cloxacillin $(5 \mu \mathrm{g})$, oxytetracylin $(30 \mu \mathrm{g})$, streptomycin $(10 \mu \mathrm{g})$ and vancomycin $(10$ 
$\mu \mathrm{g}$. All antibiotics used were obtained from (Oxoid, England), under aseptic condition dispensed and lightly pressed onto the surface inoculated plates of Muller Hinton agar (Liofilchem, Italy) with identified tested strains.

\subsubsection{Antibiotic Susceptibility Assay}

The antimicrobial resistance patterns of the identified isolates were determined using the agar disc-diffusion method (KirbyBauer technique). Each tested Vibrio spp. strain was suspended in sterile normal saline $(0.85 \%)$ to a turbidity matching to a 0.5 McFarland turbidity standard. Muller Hinton agar (Liofilchem, Italy) plates were surface swabbed with tested strain of Vibrio spp., and then the selected antibiotic discs were dispensed and lightly pressed onto the inoculated agar surface according to Coyle ${ }^{22}$. Plates were then incubated at $35 \pm 2^{\circ} \mathrm{C}$ for $24 \mathrm{~h}$. After overnight incubation, the bacterial growth around each disc was observed; the zone was then measured in $\mathrm{mm}$. The tested isolates were characterized as sensitive, intermediate or resistant based on the size of the inhibition zones around each disc, according to CLSI ${ }^{23}$ criteria.

\subsection{MAR Index}

Depend on the occurrence of the multiple resistance of isolates from each of the sample, the multiple antibiotic resistance index of the isolates is defined as $a / b$ where ' $a$ ' represents the number of antibiotics which is the particular isolate was resistant and 'b' the number of antibiotics which is exposed to the isolate ${ }^{24}$. The multiple antibiotic resistance (MAR) index was calculated as according to Ayandele et al. ${ }^{25}$.

\subsection{Statistical analysis}

Differences in results were analyzed for significance using SPSS version 24.0 for Windows. They are expressed as mean \pm standard deviation. Statistical significance was assessed using the analysis of independent sample T-test $(\mathrm{P}<0.05)$.

\section{Results}

\subsection{Isolation and Identification of Vibrio spp.}

Samples categorized as Mullet 49.2\% (60/122) and Sardine $50.8 \%(62 / 122)$, were examined for the presence of Vibrio spp. according to the standard microbiological method adopted from FDA ${ }^{19}$.

Results in Table (1) revealed that, 49.2\% (60/122) of finfish samples were yielded Vibrio spp., the incidence of contaminated Mullet samples with Vibrio spp. was 62\% (37/60), while in Sardine samples were $42 \%(26 / 62)$. Meanwhile, only 173 suspected colonies picked up from positive plates of TCBS agar according to colony characters and tested for their biochemical reactions.

The overall incidence of Vibrio spp. isolates were $39.3 \%$ (68/173); 42 (47.7\%) isolates were from Mullet samples, and 26 $(30.6 \%)$ isolates obtained from Sardine samples.
Table 1: Occurrence of Vibrio spp. in finfish samples

\begin{tabular}{|l|c|c|c|}
\hline \multirow{2}{*}{ Tested Samples } & \multicolumn{3}{|c|}{ Finfish Samples } \\
\cline { 2 - 4 } & $\begin{array}{c}\text { Mullet } \\
(\%)\end{array}$ & Sardine (\%) & Total (\%) \\
\hline No. of Samples & $60(49.2)$ & $62(50.8)$ & $122(100)$ \\
\hline $\begin{array}{l}\text { No. of Positive Finfish } \\
\text { Samples }\end{array}$ & $59(98.3)$ & $60(96.8)$ & $119(97.5)$ \\
\hline $\begin{array}{l}\text { No. of Suspected } \\
\text { Colonies Isolated on } \\
\text { TCBS Agar }\end{array}$ & 88 & 85 & 173 \\
\hline $\begin{array}{l}\text { No. of Identified } \\
\text { Vibrio spp. }\end{array}$ & $42(47.7)$ & $26(30.6)$ & $68(39.3)$ \\
\hline $\begin{array}{l}\text { No. of Samples } \\
\text { Yielded Vibrio spp. }\end{array}$ & $37(62)$ & $26(42)$ & $63(52)$ \\
\hline
\end{tabular}

Only six Vibrio spp. were identified by a conventional microbiological methods including: $V$. fluvialis, $V$. alginolyticus, $V$. cholera, V. parahemolyticus, $V$. vulnificus, and $V$. hollisae. Whereas, $V$. fluvialis recorded the highest percentage $66.2 \%$ (45/68) among identified Vibrio spp. isolates. While, $V$. alginolyticus was recorded as $14.7 \%(10 / 68)$ of isolates, $V$. cholera was $13.2 \%$ (9/68), V. parahemolyticus was $2.9 \%(2 / 68)$, $V$. vulnificus and $V$. hollisae were $1.5 \%(1 / 68)$ (Table 2). Mullet, samples yielded a higher percentage of identified Vibrio spp. isolates $62 \%(42 / 68)$ among the confirmed isolates. Moreover, $V$. fluvialis recorded the highest incidence $76.2 \%$ (32/42), V. alginolyticus was $9.5 \%$ (4/42), V. cholera was $14.3 \%$ (6/42). While, $V$. parahemolyticus, $V$. vulnificus, and $V$. hollisae were not recorded. In the meantime, Sardine samples yielded a lower percentage of identified Vibrio spp. isolates $38.2 \%(26 / 68)$ among the confirmed isolates. $V$. fluvialis recorded the highest incidence $50 \%(13 / 26), V$. alginolyticus was $23 \%$ (6/26), $V$. cholera was $11.5 \%$ (3/26), $V$. parahemolyticus was $7.7 \%(2 / 26)$, while, $V$. vulnificus and $V$. hollisae were recorded $3.8 \%(1 / 26)$ (Table 2$)$.

Table 2: Incidence of 68 Vibrio spp. isolates from finfish samples

\begin{tabular}{|l|c|c|c|c|c|c|}
\hline \multirow{2}{*}{ Vibrio spp. } & \multicolumn{2}{|c|}{ Mullet } & \multicolumn{2}{c|}{ Sardine } & \multicolumn{2}{c|}{ Total } \\
\cline { 2 - 7 } & No. & $\%$ & No. & $\%$ & No. & $\%$ \\
\hline Vibrio fluvialis & 32 & 76.2 & 13 & 50 & 45 & 66.2 \\
\hline $\begin{array}{l}\text { Vibrio } \\
\text { alginolyticus }\end{array}$ & 4 & 9.5 & 6 & 23 & 10 & 14.7 \\
\hline Vibrio cholera & 6 & 14.3 & 3 & 11.5 & 9 & 13.2 \\
\hline $\begin{array}{l}\text { Vibrio } \\
\text { parahaemolyticus }\end{array}$ & ND & ND & 2 & 7.7 & 2 & 2.9 \\
\hline $\begin{array}{l}\text { Vibrio vulnificus } \\
\text { ND }\end{array}$ & ND & 1 & 3.8 & 1 & 1.5 \\
\hline $\begin{array}{l}\text { Vibrio hollisae } \\
\text { ND }\end{array}$ & ND & 1 & 3.8 & 1 & 1.5 \\
\hline $\begin{array}{l}\text { Total of Identified } \\
\text { Vibrio spp. }\end{array}$ & 42 & 62 & 26 & 43 & 68 & 100 \\
\hline ND: not identified & & & & & & \\
\hline
\end{tabular}


Collectively, the incidence of finfish samples contaminated with Vibrio spp. was $51.6 \%(63 / 122)$. In general, V. fluvialis were significantly the highest $(\mathrm{P}<0.05) \quad 63.7 \%(40 / 63)$ in both samples of Mullet and Sardine. While, $V$. vulnificus and $V$. hollisae were the lowest 3.8\% (1/26) (Table 3).

Table 3: Incidence of Vibrio spp. on finfish samples

\begin{tabular}{|l|c|c|c|c|c|c|}
\hline \multicolumn{1}{|c|}{ Vibrio spp. } & \multicolumn{2}{|c|}{ Mullet } & \multicolumn{2}{c|}{ Sardine } & \multicolumn{3}{c|}{$\begin{array}{c}\text { Total No. of } \\
\text { Positive } \\
\text { Finfish } \\
\text { Samples }\end{array}$} \\
\cline { 2 - 8 } & No. & $\%$ & No. & $\%$ & No. & $\%$ \\
\hline Vibrio fluvialis & 27 & 73 & 13 & 50 & 40 & 63.7 \\
\hline $\begin{array}{l}\text { Vibrio } \\
\text { alginolyticus }\end{array}$ & 4 & 10.8 & 6 & 23 & 10 & 15.9 \\
\hline Vibrio cholera & 6 & 16.2 & 3 & 11.5 & 9 & 14.3 \\
\hline $\begin{array}{l}\text { Vibrio } \\
\text { parahaemolyticus }\end{array}$ & ND & ND & 2 & 7.7 & 2 & 3.2 \\
\hline $\begin{array}{l}\text { Vibrio vulnificus } \\
\text { ND }\end{array}$ & ND & 1 & 3.8 & 1 & 1.9 \\
\hline $\begin{array}{l}\text { Vibrio hollisae } \\
\text { ND }\end{array}$ & ND & 1 & 3.8 & 1 & 1.9 \\
\hline $\begin{array}{l}\text { Total of Identified } \\
\text { Vibrio spp. }\end{array}$ & 37 & 61 & 26 & 43.3 & 63 & 51.6 \\
\hline NDinotidentified & & & & & & \\
\hline
\end{tabular}

\subsection{Antibiotic Resistant Pattern}

Continues surveillance for antibacterial resistant strains in aquaculture represents a fundamental step to detect changes in the susceptibility of bacterial pathogens. In this study, all identified Vibrio's isolates (68) were tested for their susceptibility to various antibiotics (7) according to guidelines set by CLSI ${ }^{23}$. The antibiogram results of the tested strains (68) in Table (4) showed different resistance levels against seven different types of antibiotics showed varying degrees of inhibition zone. The resistance level was $87 \%(59 / 68)$ of the isolates were resistant toward cloxacillin, flowed by amoxicillin $78 \%(53 / 68)$ of the isolates, vancomycin $63 \%$ (43/68), while, resistance to amoxicillin/clavulanic acid was $57 \%$ (39/68). The resistance towards other antibiotics was found to be considerably lower towards cephalothin 26\% (18/68), oxytetracylin 23\% $(16 / 68)$ and streptomycin was $1 \%$ only $(1 / 68)$.

Moreover, this study showed a high level of MDR of isolated Vibrio spp. as many as seven antibiotics tested with the overall MAR index value ranged from 0.143 to 1 (Table 5) from both finfish samples. It is important to note that, this study result is laying serious emphasis on the need for high-level hygiene and proper cooking of seafood before eating. The statistical analysis results of mean comparison between (Mullet and Sardine) samples according to the antimicrobial zone diameter for each antibiotic showed that there was significant differences $(\mathrm{P}<0.05)$ between both samples (Mullet more than Sardine samples) for both antibiotics vancomycin and oxytetracylin, while, there was no significant differences between Mullet and Sardine samples for other antibiotics.
Table 4: Antibacterial resistance of 68 Vibrio strains isolated from finfish samples

\begin{tabular}{|c|c|c|c|c|c|c|c|c|}
\hline \multirow[b]{2}{*}{ Antibiotics } & \multicolumn{7}{|c|}{ Vibrio spp. (\%) } & \multirow[b]{2}{*}{$\frac{\frac{0}{e}}{\frac{\overrightarrow{0}}{0}}$} \\
\hline & & 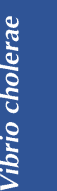 & 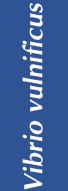 & $\begin{array}{l}\frac{8}{0} \\
\frac{\pi}{5} \\
\frac{3}{2} \\
\frac{0}{3} \\
\frac{3}{3}\end{array}$ & 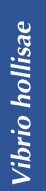 & $\begin{array}{l}\frac{8}{\pi} \\
\frac{0}{5} \\
\frac{1}{3} \\
\frac{0}{2} \\
\frac{3}{3}\end{array}$ & 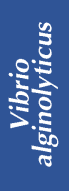 & \\
\hline \multirow{4}{*}{ Oxytetracylin } & $R$ & 22 & & 100 & 22 & & 22 & 23 \\
\hline & I & & & & 2 & & 10 & 3 \\
\hline & S & 78 & 100 & & 76 & 100 & 70 & 74 \\
\hline & $R$ & 89 & 100 & 100 & 73 & & 90 & 78 \\
\hline \multirow[t]{2}{*}{ Amoxicillin } & I & 11 & & & 18 & 100 & & 15 \\
\hline & S & & & & 9 & & 10 & 7 \\
\hline \multirow{3}{*}{$\begin{array}{l}\text { Amoxicillin/ } \\
\text { Clavulanic acid }\end{array}$} & $\mathrm{R}$ & 44 & & 50 & 60 & & 70 & 57 \\
\hline & I & 44 & & 50 & 18 & & 20 & 22 \\
\hline & $\begin{array}{l}S \\
R\end{array}$ & 12 & 100 & 50 & 22 & 100 & 10 & $\begin{array}{c}21 \\
1\end{array}$ \\
\hline \multirow[t]{3}{*}{ Streptomycin } & 1 & & & & 2 & & & 1 \\
\hline & S 1 & 100 & 100 & 50 & 98 & 100 & 100 & 98 \\
\hline & R & 100 & 100 & 100 & 96 & & 40 & 87 \\
\hline \multirow[t]{3}{*}{ Cloxacillin } & I & & & & 2 & & & 1 \\
\hline & S & & & & 2 & 100 & 60 & 12 \\
\hline & $\mathrm{R}$ & 11 & & 100 & 27 & 100 & 20 & 26 \\
\hline \multirow[t]{3}{*}{ Cephalothin } & I & 33 & & & 24 & & 20 & 24 \\
\hline & S & 56 & 100 & & 49 & & 60 & 50 \\
\hline & $R$ & 67 & & 100 & 56 & 100 & 90 & 63 \\
\hline \multirow[t]{2}{*}{ Vancomycin } & I & 11 & & & 24 & & 10 & 19 \\
\hline & $S$ & 22 & 100 & & 20 & & & 18 \\
\hline $\begin{array}{l}\text { No. of Tested } \\
\text { Isolates }\end{array}$ & & 9 & 1 & 2 & 45 & 1 & 10 & 68 \\
\hline
\end{tabular}

\section{Discussion}

\subsection{Isolation and Identification of Vibrio spp.}

Fish and seafood have been an important source of nutritive substances for centuries. However, improperly handling and processing of fish can expose consumers to pathogenic bacteria that are infectious to human and those bacteria may found naturally in the aquatic environment ${ }^{26}$. In this study, the results in Table (1) showed that, only 49.2\% (60/122) of finfish samples were yielded Vibrio spp., the incidence of contaminated Mullet samples with Vibrio spp. was higher than (62\%) Sardine samples $(42 \%)$, this is maybe due to the Mullet prefer to live near to the seashore at golf and port ${ }^{17}$, where the contamination was high in these areas with untreated sewage. Whereas, the overall prevalence of Vibrio spp. among the samples illustrated in Table (1) of identified Vibrio spp. was 39.3\% (68/173), this result is closely similar to those results reported by Azwai et al. ${ }^{27}$ and Gdoura et al. ${ }^{28}, 51.6 \%$ and $41.3 \%$, consequently. Whilst, lower percentage was reported by Raissy et al. ${ }^{29}$ was $29.3 \%$. On the other hand, many studies ${ }^{30-32}$ reported higher percentage of isolated Vibrio spp. 62.2\%, 55\%, 65.5\%, consequently. 
Table 5: Antibiotics resistance patterns and MAR index of Vibrio spp. from finfish samples

\begin{tabular}{|c|c|c|c|c|}
\hline Kind of Fish & $\begin{array}{l}\text { Antibiotic Resistance Profile } \\
\text { (No.) }\end{array}$ & Isolate Code* (No.) & $\begin{array}{l}\text { Percentage of the } \\
\text { Isolates }\end{array}$ & MAR Index \\
\hline \multirow{14}{*}{$\frac{\overline{ \pm}}{\overline{\bar{E}}}$} & $\begin{array}{c}\mathrm{VA}-\mathrm{OB}-\mathrm{AMX}-\mathrm{KF}-\mathrm{AMC} \\
-\mathrm{OT}(6)\end{array}$ & M5c1 - M19c1 (2) & 4.8 & 0.857 \\
\hline & $\mathrm{VA}-\mathrm{OB}-\mathrm{AMX}-\mathrm{KF}-\mathrm{AMC}$ & $M 1 c 1-M 3 c 3-M 22 c 2$ & 7.1 & 0.714 \\
\hline & $V A-O B-A M X-K F(4)$ & $M 1 c 3-M 17 c 2-M 21 c 2$ & 7.1 & 0.571 \\
\hline & $\mathrm{VA}-\mathrm{OB}-\mathrm{AMX}-\mathrm{AMC}(4)$ & $\begin{array}{l}M 5 c 2-M 25 c 1-M 28 c 2 \\
-M 29 c 1-M 34 c 1(5)\end{array}$ & 11.9 & 0.571 \\
\hline & $\mathrm{VA}-\mathrm{OB}-\mathrm{AMX}(3)$ & $M 1 c 2-M 3 c 2-M 59 c 2$ & 7.1 & 0.428 \\
\hline & $V A-O B-K F(3)$ & M20c2 (1) & 2.4 & 0.428 \\
\hline & & $\begin{array}{l}M 23 c 1-M 26 c 2- \\
M 27 c 1-M 29 c 2-\end{array}$ & & \\
\hline & $\mathrm{OB}-\mathrm{AMX}-\mathrm{AMC}(3)$ & $\mathrm{M} 24 \mathrm{c} 1$ - M30c1 - & & \\
\hline & $\mathrm{OB}-\mathrm{AMX}-\mathrm{AMC}(3)$ & $\begin{array}{c}\text { M33c1-M36c1- } \\
\text { M40c2 - M43c2 - } \\
\text { M53c2 - M60c1 (12) }\end{array}$ & 28.6 & 0.428 \\
\hline & $\mathrm{OB}-\mathrm{KF}-\mathrm{AMC}(3)$ & M51c1 (1) & 2.4 & 0.428 \\
\hline & $V A-O B-A M C$ & M55c1 - M57c1 (2) & 4.8 & 0.428 \\
\hline & $\mathrm{VA}-\mathrm{OB}(2)$ & M35c1 - M41c1 (2) & 4.8 & 0.286 \\
\hline & $\mathrm{OB}-\mathrm{AMX}(2)$ & $\begin{array}{c}M 46 \mathrm{c} 2-\mathrm{M} 48 \mathrm{c} 3- \\
\mathrm{M} 50 \mathrm{c} 3(3)\end{array}$ & 7.1 & 0.286 \\
\hline & $\mathrm{OB}(1)$ & $\begin{array}{c}\text { M10c1 - M29c3 - } \\
\text { M39c2 - M56c2 - } \\
\text { M58c1 (5) }\end{array}$ & 11.9 & 0.143 \\
\hline \multirow{11}{*}{ 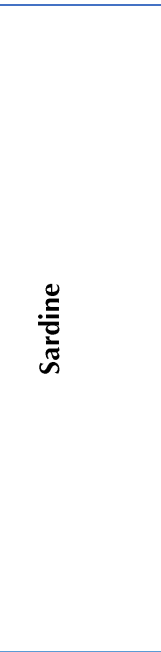 } & $\begin{array}{c}\mathrm{VA}-\mathrm{OB}-\mathrm{AMX}-\mathrm{S}-\mathrm{KF}- \\
\mathrm{AMC}-\mathrm{OT}(7)\end{array}$ & S59c2 (1) & 3.8 & 1 \\
\hline & $\begin{array}{c}\mathrm{VA}-\mathrm{OB}-\mathrm{AMX}-\mathrm{KF}-\mathrm{AMC} \\
-\mathrm{OT}(6)\end{array}$ & $\begin{array}{l}\mathrm{S} 11 \mathrm{c} 1-\mathrm{S} 31 \mathrm{c} 3-\mathrm{S} 38 \mathrm{c} 1 \\
-\mathrm{S} 42 \mathrm{c} 2-\mathrm{S} 57 \mathrm{C} 2(5)\end{array}$ & 19.2 & 0.857 \\
\hline & $\mathrm{VA}-\mathrm{OB}-\mathrm{AMX}-\mathrm{KF}-\mathrm{OT}$ & S13c2 -S57c1 (2) & 7.7 & 0.714 \\
\hline & $\mathrm{VA}-\mathrm{OB}-\mathrm{AMX}-\mathrm{KF}-\mathrm{AMC}$ & S14c1 (1) & 3.8 & 0.714 \\
\hline & $\mathrm{VA}-\mathrm{OB}-\mathrm{AMX}-\mathrm{AMC}-\mathrm{OT}$ & $\mathrm{S} 40 \mathrm{c} 2-\mathrm{S} 41 \mathrm{c} 2(2)$ & 7.7 & 0.714 \\
\hline & VA - OB - AMX - OT (4) & $\mathrm{S} 12 \mathrm{c} 1-\mathrm{S} 17 \mathrm{C} 1(2)$ & 7.7 & 0.571 \\
\hline & $\mathrm{VA}-\mathrm{OB}-\mathrm{AMX}-\mathrm{AMC}(4)$ & $\begin{array}{c}\mathrm{S} 27 \mathrm{c} 1-\mathrm{S} 30 \mathrm{c} 1-\mathrm{S} 32 \mathrm{c} 3 \\
-\mathrm{S} 36 \mathrm{c} 1(4)\end{array}$ & 15.4 & 0.571 \\
\hline & AMX - AMC - OT (3) & S9c1 (1) & 3.8 & 0.428 \\
\hline & $\mathrm{VA}-\mathrm{OB}-\mathrm{AMX}(3)$ & $\begin{array}{c}\mathrm{S} 28 \mathrm{c} 1-\mathrm{S} 33 \mathrm{c} 3-\mathrm{S} 34 \mathrm{c} 2 \\
(3)\end{array}$ & 11.5 & 0.428 \\
\hline & $V A-O B-K F(3)$ & $\mathrm{S} 54 \mathrm{c} 2(1)$ & 3.8 & 0.428 \\
\hline & $\mathrm{VA}-\mathrm{OB}(2)$ & $\begin{array}{c}\mathrm{S} 26 \mathrm{c} 2-\mathrm{S} 29 \mathrm{c} 1-\mathrm{S} 39 \mathrm{c} 4 \\
(3)\end{array}$ & 11.8 & 0.286 \\
\hline
\end{tabular}

Whereas, Noorlis et al. ${ }^{26}$ and Sudha et al. ${ }^{32}$ reported much higher results than the other studies ranged between $98.7 \%$ and $90.0 \%$ of Vibrio spp. isolated from fish commonly sold in some Nigerian markets. These wide differences in the isolation of Vibrio spp. by various scientists from various sources might be due to geographic, seasonal, salinity, temperature variations and procedures adopted for isolation ${ }^{33}$. Furthermore, Tables $(2,3)$ indicated that the ubiquitous $V$. fluvialis, which is represented the larger sector of the isolated Vibrio's in Mullet and Sardine samples with $66.2 \%$ from the total number of isolated Vibrio strains, this high prevalence may be attributed to their high salt tolerance ability, this is in agreement with other studies 26,30 . Vibrio alginolyticus is considered as the major fish pathogen causing severe mortality in various fish species throughout the world and its virulence to fish is vary from species to another and within same species ${ }^{5}$. In the current study, the percentage of the retrieved isolates of $V$. alginolyticus was $14.7 \%$ (Sardine was more contaminated than Mullet samples), this result agrees with Sudha et al. ${ }^{32} 18.1 \%$, this is maybe explained by seawater is the normal habitat for $V$. alginolyticus and was isolated from seawater and seafood in many parts of the world. Many other studies indicated that the most predominant Vibrio spp. was $V$. alginolyticus ${ }^{29,32}$. The current study also indicated that the presence of $V$. cholerae $(13.2 \%)$ was in Mullet more than in Sardine samples, this is in agreement with Sudha et al. ${ }^{32}$. Presence of $V$. cholera in seawater considered as an evidence for probability seawater pollution with un-treated sewage ${ }^{34}$. Meanwhile, $V$. parahemolyticus considered one of the main 
food poisoning pathogens linked to raw or inefficiently cooked seafood feeding ${ }^{35}$. The present study indicated that the average percentage of $V$. parahemolyticus was $2.9 \%$, which was isolated from Sardine samples only, in contrast to the results obtained by others studies ${ }^{4,32,34}$ which indicated that, the $V$. parahemolyticus was predominant species of the examined fish samples. Besides, in the current study, the incidence of $V$. vulnificus was $1.5 \%$, which is isolated only from Sardine samples, the $V$. vulnificus, is a highly pathogenic Vibrio that present in moderate loads in the common reservoirs such as mussels, shellfishes and mollusks ${ }^{35}$, besides, $V$. vulnificus is a well-known to be an eminent cause of cellulitis and septicemia in fishermen, swimmers and people handling infected fishes ${ }^{35}$. In conclusion, the isolated Vibrio spp. from finfish samples showed a high incidence of $V$. fluvialis followed by $V$. alginolyticus, while the least incidence was observed in $V$. vulnificus and $V$. hollisae among finfish sold in two major markets in Tripoli, Libya.

\subsection{Antibiotic Resistant Pattern}

Recently, an increase in the emergence of MDR bacteria is worrying and begins to erode our antibiotics armamentarium to combat antibiotic resistance and thus limiting therapeutics options to the present-day clinicians ${ }^{26}$. There is a necessity of coordination between human, veterinarian, and environmental sectors to clarify the occurrence of resistant pathogens in humans, animals and in the environment. Table (4) shows all isolated Vibrio spp. having different levels of resistance to different antibiotics used and varying degrees of a zone of inhibition. Results obtained in this study indicated that the majority of isolated Vibrio spp. were resistant to cloxacillin (87\%) and vancomycin (63\%), this may be due to both antibiotics have narrow spectrum against Gram-positive bacteria only, this is in agreement with another study by Udoulla et al. ${ }^{36}$ showed a high level of resistance to vancomycin. Amoxicillin is moderate spectrum antibiotic, according to the data from WHO in general amoxicillin, streptomycin and carbenicillin considered as critically important in human medicine to treat serious Gramnegative infections. This is in contrast to results obtained in this study that showed high resistance against amoxicillin with $78 \%$, similarly to study in Italy, their result showed that over $70 \%$ of the all isolated Vibrio spp. were resistant to amoxicillin ${ }^{13}$, as well as, result obtained by Sudha et al. ${ }^{3}$ showed high rate of resistance to $\beta$-lactamase this could be explained with the susceptibility of these antibiotics to $\beta$-lactamase expressed by tested Vibrio spp. Amoxicillin/clavulanic acid is a broad-spectrum antibiotic; current study results indicated moderate resistance against it with $57 \%$. On the other hand, the results of this study showed slightly resistance against other antibiotics, cephalothin with $26 \%$ of resistance. This result nearly similar to those results obtained by Scarano et al. ${ }^{14}$ were resistance to cephalothin was observed in $37.3 \%$ of all tested strains, and in contrast, to another study reported high resistance to the cephalothin with $80 \%$ of all tested strains ${ }^{3}$. Tetracyclines are a group of antibiotics widely recommended to use in human and veterinary practices for the treatment of vibriosis because of their broad-spectrum activity, low toxicity and their cost-effectiveness ${ }^{37-39}$. Oxytetracylin is the most common antibiotic licensed in aquaculture in Europe; it is a drug of choice for vibriosis in aquaculture. Several studies support the great susceptibility of Vibrio spp. to tetracycline ${ }^{15}$, which agree with results obtained by Han et al. ${ }^{39}$ were reported that the tetracycline's one of the antibiotics were highly effective against $V$. parahemolyticus strains, while, Sudha et al. ${ }^{3}$ indicated that, no resistance to tetracycline among their isolates, this is opposite to the results obtained in this study that revealed resistance to oxytetracylin (23\%) of tested isolates, another study by Udoulla et al. ${ }^{36}$ showed an agreement to our results which recorded a high level of resistance to tetracycline. These high levels of resistance property could be stated by the furthered chance to exchange genetic resistance determinants spotted on the plasmids among microorganisms and due to the extensive use of antibiotics in fishery and for the treatment of different kinds of fish infections ${ }^{40}$. This result is a critical alarm for the public health authorities to the ongoing antibiotic resistance resulting from the continuous dumping of municipal untreated sewage into seawater ${ }^{30}$. This study concerns the determination of the profiles of antibiotic resistance of Vibrio spp. recognized as causative agents of important diseases in the Mediterranean Sea and fish farming to all isolated Vibrio spp. To summarize, the current study showed a high level of sensitivity with $98 \%$ of total tested Vibrio spp. to streptomycin followed by oxytetracylin with $74 \%$, these results agree with previous study have shown that streptomycin, tetracycline, erythromycin and bacitracin were active against Vibrio spp. ${ }^{41}$. In spite of the fact, in previous study, streptomycin and tetracycline were considered to be effective against Vibrio spp. and this result agrees with numerous studies ${ }^{6}$. In contrast to another study, which recorded high resistance to streptomycin ${ }^{3}$. Moreover, this study showed a high level of MDR of isolated Vibrio spp. as many as seven antibiotics tested with the overall MAR index value ranged from 0.143 to 1 (Table 5) from both finfish samples. It is important to note that, this study result is laying serious emphasis on the need for high-level hygiene and proper cooking of seafood before eating.

\section{Conclusion}

The results obtained in this study showed a high incidence of Vibrio spp. in finfish samples and this suggests that fish sold in Tripoli fish markets represent a potential health hazard. This is because some isolated strains were able to resist some popular antibiotics used in treatment of human and aquaculture. This finding also indicated that, antibiotic resistance strains are common in raw finfish sold in the markets. Therefore, Libyan regulatory authority should require fish marketing, markets, fish restaurants etc. to adapt quality guarantee system such as HACCP and better treatment control system for the urban sewage especially in the cities near shores to prevent the presence of these MDR strains on the fish and seawater.

Acknowledgement: We would like to thank people in the quality control, and disease of marine living organism's laboratory, Marine Biology Research Center (MBRC), Tajoura - Libya, for their assistant and corporation.

Author contribution: Hesham Taher Naas, conceived and designed the study, and undertook the literature research. All authors participated in 
the experiment and data acquisition. Hanan Lotfi Eshamah and Emad Ramadan Abodaia performed the data analysis and carried out the statistical analysis, prepared, reviewed and drafted the manuscript. All authors approved the final version before submission. All authors have read and agreed to the published version of the manuscript.

Funding: This research received no external funding.

Conflict of interest: The authors declare no conflicts of interest.

\section{References}

1. Zhang, X., Lin, H., Wang, X., Austin, B. (2018) Significance of Vibrio species in the marine organic carbon cycle - A review. Science China Earth Sciences, 61. https://doi.org./10.1007/s11430-017-9229-X.

2. Pujalte, M., Sitjà-Bobadilla, A., Álvarez-Pellitero, P., \& Garay, E. (2003). Carriage of potentially fish-pathogenic bacteria in Sparus aurata cultured in Mediterranean fish farms. Diseases of Aquatic Organisms, 54, 119-126. https://doi.org/10.3354/dao054119

3. Sudha, S., Divya, P. S., Francis, B., \& Hatha, A. A. (2012). Prevalence and distribution of Vibrio parahaemolyticus in finfish from Cochin (south India). Veterinaria italiana, 48(3), 269-281. PMID: 23038073

4. Saad, S., Samir, M., \& Abd El Maksod, H. (2015). Incidence of Vibrio species in fish with special emphasis on the effect of heat treatments. Benha Veterinary Medical Journal, 29(1), 38-44. https://doi.org/10.21608/bvmj.2015.31788

5. Annie Selva Sonia, G., \& Lipton, A. P. (2012). Pathogenicity and antibiotic susceptibility of Vibrio species isolated from the captive-reared tropical marine ornamental blue damsel fish, Pomacentrus caeruleus (Quoy and Gaimard, 1825). Indian Journal of Geo-Marine Sciences, 41(4), 348-354. Availailable at http://nopr.niscair.res.in/bitstream/123456789/14552/1/IJ MS\%2041\%284\%29\%20348-354.pdf

6. Jennings, S., Stentiford, G., Leocadio, A.M., Je ery, K.R., Metcalfe, J.D., Katsiadaki, I., Auchterlonie, N.A., Mangi, S.C., Pinnegar, J.K., Ellis, T., et al., (2016) Aquatic food security: Insights into challenges and solutions from an analysis of interactions between fisheries, aquaculture, food safety, human health, fish and human welfare, economy and environment. Fish and fishers 17 (4) 893-938. https://doi.org/10.1111/faf.12152.

7. Rose, J. M., Gast, R. J., Bogomolni, A., Ellis, J. C., Lentell, B. J., Touhey, K., \& Moore, M. (2009). Occurrence and patterns of antibiotic resistance in vertebrates off the northeastern United States coast. FEMS Microbiology Ecology, 67(3), 421-431. https://doi.org/10.1111/j.15746941.2009.00648.x

8. Laganà, P., Caruso, G., Minutoli, E., Zaccone, R., \& Delia, S. (2011). Susceptibility to antibiotics of Vibrio spp. and Photobacterium damsela ssp. piscicida strains isolated from Italian aquaculture farms. New microbiologica, 34(1), 5363. PMID: 21344147
9. Silbergeld, E. K., Graham, J., \& Price, L. B. (2008). Industrial food animal production, antimicrobial resistance, and human health. Annual Review of Public Health, 29(1), 151-169.

https://doi.org/10.1146/annurev.publhealth.29.020907.09 $\underline{0904}$

10. Guglielmetti, E., Korhonen, J. M., Heikkinen, J., Morelli, L., \& Von Wright, A. (2009). Transfer of plasmidmediated resistance to tetracycline in pathogenic bacteria from fish and aquaculture environments. FEMS Microbiology Letters, 293(1), 28-34. https://doi.org/10.1111/j.1574-6968.2009.01512.x

11. Zanetti, S., Spanu, T., Deriu, A., Romano, L., Sechi, L., \& Fadda, G. (2001). In vitro susceptibility of Vibrio spp. isolated from the environment. International Journal of Antimicrobial Agents, 17(5), 407-409. https://doi.org/10.1016/s0924-8579(01)00307-7

12. Duran, G. M., \& Marshall, D. L. (2005). Ready-to-Eat shrimp as an international vehicle of antibiotic-resistant Bacteria. Journal of Food Protection, 68(11), 2395-2401. https://doi.org/10.4315/0362-028x-68.11.2395

13. Kumar, S., Lekshmi, M., Parvathi, A., Nayak, B.B. and Varela, M.F. (2016). Antibiotic Resistance in SeafoodBorne Pathogens. In Foodborne Pathogens and Antibiotic Resistance, O.V. Singh (Ed.). https://doi.org/10.1002/9781119139188.ch17

14. Scarano, C., Spanu, C., Ziino, G., Pedonese, F., Dalmasso, A., Spanu, V., Virdis, S., \& De Santis, E. P. (2014). Antibiotic resistance of Vibrio species isolated from Sparus aurata reared in Italian mariculture. The new microbiologica, 37(3), 329-337. PMID: 25180847

15. Kumar, S., Lekshmi, M., Parvathi, A., Nayak, B.B. and Varela, M.F. (2016). Antibiotic Resistance in SeafoodBorne Pathogens. In Foodborne Pathogens and Antibiotic Resistance, O.V. Singh (Ed.). https://doi.org/10.1002/9781119139188.ch17

16. Osundiya, O., Oladele, R., \& Oduyebo, O. (2013). Multiple antibiotic resistance (MAR) indices of Pseudomonas and Klebsiella species isolates in Lagos University teaching hospital. African Journal of Clinical and Experimental Microbiology, 14(3). https://doi.org/10.4314/ajcem.v14i3.8

17. Bariche, M. (2012). FAO Species Identification Guide for Fishery Purposes-Field identification guide to the living marine resources of the eastern and southern Mediterranean. Food and Agriculture Organization. Available at http://www.fao.org/3/i1276b/i1276b00.htm

18. Food and Drug Administration (FDA). (2004). Bacteriological analytical manual online. Ch. 9. 8th ed., Revision A 1998 AOAC international. ARLINGTON, VA. Available at: https://www.fda.gov/food/laboratory-methodsfood/bam-chapter-9-vibrio 
19. Austin, B. (2006). The Bacterial Microflora of Fish, Revised. The Scientific World JOURNAL, 6, 931-945. https://doi.org/10.1100/tsw.2006.181

20. Food and Drug Administration (FDA) Bacteriological analytical manual. (1992). 7th ed. USA. Available at: https://www.academia.edu/23345561/Bacteriological Anal ytical Manual

21. Kaysner, C. A., DePaola, A., \& Jones, J. (2019). BAM Chapter 9: Vibrio. FDA. Available at https://www.fda.gov/food/laboratory-methods-food/bamchapter-9-vibrio

22. Coyle, M. B., \& American Society for Microbiology. (2005). Manual of antimicrobial susceptibility testing. American Society for Microbiology. Washington D.C; 2539. ISBN: 9781555813482

23. Clinical and laboratory standards institute (CLSI). (2020). Methods for Antimicrobial Broth Dilution and Disk Diffusion Susceptibility Testing of Bacteria Isolated From Aquatic Animals (2nd Edition). Available at https://clsi.org/standards/products/veterinarymedicine/documents/vet03/

24. Krumperman, P. H. (1983). Multiple antibiotic resistance indexing of Escherichia coli to identify high-risk sources of fecal contamination of foods. Applied and Environmental Microbiology, 46(1), 165-170. https://doi.org/10.1128/aem.46.1.165-170.1983

25. Ayandele, A. A., Oladipo, E. K., Oyebisi, O., \& Kaka, M. O. (2020). Prevalence of Multi-Antibiotic Resistant Escherichia coli and Klebsiella species obtained from a Tertiary Medical Institution in Oyo State, Nigeria. Qatar Medical Journal, 2020(1), 9. https://doi.org/10.5339/qmj.2020.9

26. Noorlis, A., Ghazali, F. M., Cheah, Y. K., Tuan Zainazor, T. C., Wong, W. C., Tunung, R., Pui, C. F., Nishibuchi, M., Nakaguchi, Y. \& Son, R. (2011). Antibiotic resistance and biosafety of Vibrio cholerae and Vibrio parahaemolyticus from freshwater ish at retail level. International Food Research Journal, 18(4). Available at http://www.ifrj.upm.edu.my/18\%20(04)\%202011/(45)IFR I-2011-266.pdf

27. Azwai, S., Alfallani, E., Abolghait, S., Garbaj, A., Naas, H., Moawad, A., Gammoudi, F., Rayes, H., Barbieri, I., \& Eldaghayes, I. (2016). Isolation and molecular identification of Vibrio spp. by sequencing of $16 \mathrm{~S} \mathrm{rDNA}$ from seafood, meat and meat products in Libya. Open Veterinary Journal, 6(1), 36-43. https://doi.org/10.4314/ovj.v6i1.6

28. Gdoura, M., Sellami, H., Nasfi, H., Trabelsi, R., Mansour, S., Attia, T., Nsaibia, S., Valleys, T., Gdoura, R., \& Siala, M. (2016). Molecular detection of the three major pathogenic Vibrio species from seafood products and sediments in Tunisia using real-time PCR. Journal of Food Protection, 79(12), 2086-2094. https://doi.org/10.4315/0362-028x.jfp-16-205
29. Raissy, M., Rahimi, E., Azargun, R., Moumeni, M., Sohrabi, H. (2015). Molecular Detection of Vibrio spp. in Fish and Shrimp from the Persian Gulf. Journal of Food Biosciences and Technology, 05(2), 49-52. Available at http://jfbt.srbiau.ac.ir/article_7003_6.html

30. Altakaly, M. B. (2015). Detection of the most common vibrio's affecting sea bream fish at the coastal area of Tripoli, Libya. Master Thesis Faculty of Veterinary Medicine, University of Tripoli, Libya.

31. Vu, T. T., Aalter, T., \& Huehn, S. (2018). Prevalence of Vibrio spp. in retail seafood in Berlin, Germany. Journal of Food Protection, 81(4), 593-597. https://doi.org/10.4315/0362-028x.jfp-17-366

32. Sudha, S., Mridula, C., Silvester, R., \& Hatha, A. A. M. (2014). Prevalence and antibiotic resistance of pathogenic Vibrios in shellfishes from Cochin market. Indian J. of Geo. Marine Sci, 43(5), 815-824. Available at http://nopr.niscair.res.in/bitstream/123456789/28767/4/IJ MS\%2043\%285\%29\%20815-824.pdf.

33. Sousa, O. V., Vieira, R. H., Menezes, F. G., Reis, C. M., \& Hofer, E. (2004). Detection of vibrio parahaemolyticus and vibrio cholerae in oyster, Crassostrea rhizophorae, collected from a natural nursery in the coco river Estuary, Fortaleza, Ceará, Brazil. Revista do Instituto de Medicina Tropical de Sáo Paulo, 46(2), 59-62. https://doi.org/10.1590/s0036$\underline{46652004000200001}$

34. Tan, C. W., Rukayadi, Y., Hasan, H., Thung, T. Y., Lee, E., Rollon, W. D., Hara, H., Kayali, A. Y., Nishibuchi, M., \& Radu, S. (2020). Prevalence and antibiotic resistance patterns of vibrio parahaemolyticus isolated from different types of seafood in Selangor, Malaysia. Saudi Journal of Biological Sciences, 27(6), 1602-1608. https://doi.org/10.1016/j.sjbs.2020.01.002.

35. Austin, B., \& Austin, D. A. (2012). Bacterial Fish Pathogens: Disease of Farmed and Wild Fish (5th ed.). Springer Netherlands. https://doi.org/10.1007/978-94007-4884-2.

36. Udoulla, A., Mizan, F.R., Park, H., Byun, K.H., Lee, N., Park, S.H. \& Do Ha, S. (2019). Genetic Relationship, Virulence Factors, Drug Resistance Profile and Biofilm Formation Ability of Vibrio parahaemolyticus Isolated From Mussel. www.frontiersin.org. doi: 10.3389/fmicb.2019.00513.

37. Ashrafudoulla, M., Mizan, M. F., Park, H., Byun, K., Lee, N., Park, S. H., \& Ha, S. (2019). Genetic relationship, virulence factors, drug resistance profile and Biofilm formation ability of vibrio parahaemolyticus isolated from mussel. Frontiers in Microbiology, 10. https://doi.org/10.3389/fmicb.2019.00513

38. Han, F., Walker, R. D., Janes, M. E., Prinyawiwatkul, W., $\&$ Ge, B. (2007). Antimicrobial susceptibilities of vibrio parahaemolyticus and vibrio vulnificus isolates from Louisiana Gulf and retail raw oysters. Applied and 
Environmental Microbiology, 73(21), 7096-7098. https://doi.org/10.1128/aem.01116-07

39. Silva, P. P., Paula, F. C., Guerra, W., Silveira, J. N., Botelho, F. V., Vieira, L. Q., Bortolotto, T., Fischer, F. L., Bussi, G., Terenzi, H., \& Pereira-Maia, E. C. (2010). Platinum (II) compounds of tetracyclines as potential anticancer agents: Cytotoxicity, uptake and interactions with DNA. Journal of the Brazilian Chemical Society, 21(7), 1237-1246. $\quad$ https://doi.org/10.1590/s010350532010000700011

40. Ottaviani, D., Leoni, F., Talevi, G., Masini, L., Santarelli, S., Rocchegiani, E., Susini, F., Montagna, C., Monno, R.,
D’Annibale, L., Manso, E., Oliva, M., \& Pazzani, C. (2013). Extensive investigation of antimicrobial resistance in vibrio parahaemolyticus from shellfish and clinical sources, Italy. International Journal of Antimicrobial Agents, 42(2), 191-193. https://doi.org/10.1016/j.ijantimicag.2013.05.003

41. Amalina, N.Z., Santha, S., Zulperi, D., Amal, M.N.A, Yusof, M.T., Zamrri-Saad, M \& Ina-Salwany, M. Y. (2019) Prevalence, antimicrobial susceptibility and plasmid profiling of Vibrio spp. isolated from cultured groupers in Peninsular Malaysia. BMC Microbiol 19, 251 (2019). https://doi.org/10.1186/s12866-019-1624-2. 45.

Cite this article as: Abodaia, E. R., Eshamah, H. L., \& Naas H. T. (2020). Prevalence of Antibiotic Resistant Vibrio spp. in Finfish Sold in Tripoli Fish Markets, Libya. The North African Journal of Food and Nutrition Research. July - December, 04(08), 309-317. https://doi.org/10.5281/zenodo.4294173 